\title{
DOES VC BACKING AFFECT BRAND STRATEGY IN TECHNOLOGY
}

\section{VENTURES?}

\author{
Enrico Forti (corresponding author) \\ University College London \\ UCL School of Management \\ 1 Canada Square \\ London E14 5AB \\ United Kingdom \\ e.forti@ucl.ac.uk
}

\author{
Federico Munari \\ University of Bologna, \\ Department of Management \\ Via Capo di Lucca, 34 \\ 40126 Bologna, Italy \\ federico.munari@unibo.it
}

\section{Chunxiang Zhang}

Guangdong University of Economics and Finance, School of Entrepreneurship Education

Guangzhou, Guangdong, China

caula@126.com

\section{Running head: VC BACKING AND BRAND STRATEGY IN TECHNOLOGY} VENTURES

Keywords: Technology Ventures, New Venture Strategies, Venture Capital, Brands, Resource-based View

This article has been accepted for publication and undergone full peer review but has not been through the copyediting, typesetting, pagination and proofreading process which may lead to differences between this version and the Version of Record. Please cite this article as doi: $10.1002 /$ sej. 1318 
Research Summary: The resource-based view of the firm characterizes brands as important resources for firm growth and competitive advantage. Existing studies offer theory and evidence that venture capital (VC) firms enhance the growth of new firms along different dimensions. It is not clear however whether and how VC backing affects the development of brand assets in new technology ventures. In a study of VC-backed and non-VC-backed nanotechnology ventures in the United Kingdom we find a positive effect of VC backing on the development of brand assets. We also find that VC-backed technology ventures tend to create brand assets with a wider scope, which can be deployed across multiple different product-markets.

Managerial Summary: Brand strategy is critical for the success of entrepreneurial firms and can be challenging for firms operating in nascent industries that aim to commercialize innovations stemming from general purpose technologies. Such firms face dilemmas on whether to diversify or not into different product-markets, how many brand assets to develop, and whether to leverage a brand asset across multiple product categories. In a study of nanotechnology ventures we find that venture capital investors can affect the development of brand strategy: VC-backed ventures tend to develop more brand assets compared with non-VC-backed ventures and tend to create brand assets with a wider scope, which can be deployed across multiple different product-markets.

Keywords: Technology Ventures, New Venture Strategies, Venture Capital, Brands, Resource-based View 


\section{INTRODUCTION}

Brands are characterized by the resource-based view of the firm as key resources for firm growth and competitive advantage (e.g., Levinthal and Wu, 2010; Wernerfelt, 1984).

Existing theory and evidence document strong links between Venture Capital (VC) funding and different dimensions of entrepreneurial growth, with particular emphasis on innovation (e.g., Fitza, Matusik, and Mosakowski, 2009; Hellmann and Puri, 2000; Hsu, 2006; Lahr and Mina, 2016). Yet there is a limited understanding on whether and how VC backing affects the brand strategies of technology ventures - i.e., how firms develop and deploy brand $\operatorname{assets}^{1}$ for the commercialization of products and services.

Understanding the link between VC backing and brand strategy is important to start-up entrepreneurs and managers at VC firms alike. Entrepreneurs often establish technology ventures to develop and bring to market new products and services stemming from scientific breakthroughs, facing considerable technological and market uncertainty (Clarysse, Bruneel, and Wright, 2011). New ventures spend substantial resources to convert promising technologies into commercial applications and founders have often science/technological backgrounds with competences mainly related to $\mathrm{R} \& \mathrm{D}$ rather than marketing and commercialization (Brush, Greene, and Hart, 2001; Ott, Eisenhardt, and Bingham, 2017; Rindova et al., 2012).

Research shows that VC backing is a key transition in the lifecycle of technology ventures (Lahr and Mina, 2016; SØRENSEN, 2007) while the media often depicts it as a watershed event that will impact both the quantity and direction of R\&D and marketing activities (e.g.,

\footnotetext{
${ }^{1}$ Firms can protect with trademarks different types of brand assets that identify the business or products and services. These include words and logos, but also color, and even non-visual marks such as sound, scent, and flavour (USPTO, 2018).
} 
TechCrunch, 2012). Empirical evidence on the impacts of VCs on their portfolio companies shows that early-stage ventures that secure VC backing receive valuable monetary and non-monetary support (Hellmann and Puri, 2000, 2002). VC backing has been shown to enhance ventures' innovative productivity (Croce, Martí, and Murtinu, 2013; Dushnitsky and Lenox, 2005; Engel and Keilbach, 2007; Lahr and Mina, 2016), accelerate scaling up and resource acquisition (Davila, Foster, and Gupta, 2003), foster the development of cooperative technology commercialization strategies (Hsu, 2006), and increase financial performance (Fitza et al., 2009; SØRENSEN, 2007). It is not clear however to what extent VC backing impacts brand strategy.

Brands are important resources and managers have been shown to spend a considerable portion of their budgets to build brand equity (Madden, Fehle, and Fournier, 2006). Developing brand assets can impact in a number of different ways the prospects of new technology ventures, from strengthening the effectiveness of commercialization and developing customer loyalty (Krasnikov, Mishra, and Orozco, 2009), to attracting new talent and investors (Vomberg, Homburg, and Bornemann, 2014; Wry, Lounsbury, and Jennings, 2014), and enabling options for diversification (Sakhartov and Folta, 2014).

Importantly, brand assets are intimately linked with trademarks — the legal mechanisms that protect the distinctive signs which identify products or services of a particular organization (Krasnikov et al., 2009). As trademarks can be renewed indefinitely, brand assets provide technology ventures with rare scale-free resources that can extend and complement the protection offered by patents (Levinthal and Wu, 2010; Mendonça et al., 2004; Rujas, 1999) 
and other intellectual property rights. Brand assets can be therefore an important source of competitive advantage (Morgan, Vorhies, and Mason, 2009).

New firms sustain considerable efforts to build brand assets and research has convincingly shown the reliability of trademarks as a proxy to capture the outcomes of these efforts (Block et al., 2014b; Krasnikov et al., 2009). An analysis of the antecedents of brand activities in new technology ventures is however almost entirely absent in the entrepreneurship literature. In particular, despite evidence on the importance of downstream activities to convert promising innovations into sought-after products (Chandy et al., 2006; Sarangee and Echambadi, 2014), no study we are aware of has assessed to what extent VC backing affects the brand strategy of technology ventures. This is a critical omission because there is strong evidence that new ventures that develop brand assets are more likely to achieve successful growth outcomes (Guzman and Stern, 2015).

The lack of research on the effects of VC backing on technology ventures' brand strategy is at odds with a tradition of studies showing how VC backing can shape the upstream innovation processes and outcomes of startups. Scholars frequently resorted to patent data to proxy innovative outcomes, generally showing a positive impact of $\mathrm{VC}$ backing on patenting (e.g., Alvarez-Garrido and Dushnitsky, 2016; Arqué-Castells, 2012; Bertoni and Tykvová, 2015; Fitza et al., 2009), but did not provide insights on whether and how VC backing affects the development of downstream resources like brand assets ${ }^{2}$. Innovation is a complex process leading from invention to commercialization and many patented inventions are rarely

\footnotetext{
${ }^{2}$ New technology ventures rarely possess internal capabilities related to marketing and brand development, a gap which can significantly hamper their growth (Brush et al., 2001; Rindova et al., 2012).
} 
converted into commercialized innovations (Arora, Fosfuri, and Gambardella, 2001; Chandy et al., 2006; Hsu, 2006; Mendonça et al., 2004). While patents are fairly effective proxies for characterizing the upstream side of firms' innovative processes-i.e., the creation of inventions - they poorly represent the downstream side - i.e., the commercialization of innovations in the form of new products and services. We try to complete the picture by studying whether VC backing affects the brand strategy of technology ventures.

We exploit a hand-collected panel dataset on 192 new ventures from the micro and nanotechnology sector in the United Kingdom to compare the brand assets of VC-backed ventures and non-VC-backed ventures. We use trademark filings to observe brand development in VC-backed companies before and after their first round of VC funding and draw comparisons along two different dimensions: the number of new brand assets and the extent to which firms leverage a common brand asset to market different kinds of products. We address the possibility of unobserved self-selection into VC-backing by using coarsened exact matching and an instrumental variable approach. Results suggest a positive effect of VC backing on the development of brand assets and that after receiving VC funding technology ventures tend to create brand assets with a wider scope, which can be deployed across multiple different product-markets.

Overall, our study contributes to research investigating the importance of VCs for start-ups' growth trajectories and to those studies that have highlighted the importance of scale free resources and downstream marketing activities in nascent industries.

\section{THEORETICAL BACKGROUND}

Brands and the Development of Scale Free Resources in New Technology Ventures 
In recent years, the share of budget dedicated to branding has seen a great expansion in the context of technology ventures, reflecting a need for increasingly elaborated marketing strategies for luring consumers away from more established firms (Lambert-Pandraud and Laurent, 2010) and generating demand for novel products and services (Vomberg et al., 2014).

Brand assets are important for technology ventures because, similar to other intangibles, such as patents and trade secrets, they are scale free resources characterized by high fungibility and low opportunity cost (Levinthal and $\mathrm{Wu}, 2010)$. That is, as a brand asset, such as a name, a logo, a color, a sound, or even a fragrance does not face limits on the number of activities in which it can be used, it affords technology ventures to derive synergies across activities and products (Ref and Shapira, 2017).

Brand assets protected with trademarks become a strategic resource that can enhance a technology venture ability to acquire legitimation among relevant audiences and generate returns from products or services (Block et al., 2014b; Guzman and Stern, 2015; Mendonça et al., 2004). Moreover, in the specific context of technology ventures, brand assets and the trademarks that protect them can potentially provide some form of advantage over competitors even after a patent has expired because a trademark can be renewed indefinitely.

Technology ventures have been usually regarded as patent- rather than trademark-intensive, reflecting their focus on inventions and the relative high costs of $R \& D$ (Arora et al., 2001) $)^{3}$. However, brand assets are increasingly important for technology ventures operating both in consumer and industrial markets (Granqvist, Grodal, and Woolley,

\footnotetext{
${ }^{3}$ While patents are directly related to the technological aspects of innovation, trademarks are mostly associated with its commercialization side and firms' downstream market-related activities (Rujas, 1999; Schmoch and Gauch, 2009).
} 
2013; Grodal, 2018).

Previous literature has shown that trademarks capture a significant portion of firms' efforts to develop brand assets (Block et al., 2014b; Flikkema, De Man, and Castaldi, 2014; Krasnikov et al., 2009) and studies that have focused on the consequences of branding have found a strong correlation with new ventures' growth and survival (Guzman and Stern, 2015). However, research on the antecedents of technology ventures' brand strategy is still limited and in an early stage of development, with only a few studies analyzing the determinants of the use of trademarks (Amara, Landry, and Traoré, 2008; Gallié and Legros, 2012; Mendonça et al., 2004) and a more sizeable number of studies looking at the consequences of trademarking, such as market value (Block et al., 2014b; Krasnikov et al., 2009), or employment levels (Greenhalgh and Rogers, 2012).

New technology ventures face multiple challenges in developing a brand strategy and specific brand assets, providing an interesting and unique context for research. First, startups have no established identity at the outset and commercialization strategies have to be built from scratch (Marx, Gans, and Hsu, 2014) along with brand assets, which can be extremely important for customer acquisition and therefore for the survival of the company (Vomberg et al., 2014). Founders of new technology ventures typically have technical and scientific backgrounds and rarely possess capabilities related to marketing and brand asset development (Brush et al., 2001; Rindova et al., 2012). Second, branding generates direct costs — such as hiring a design firm to create brand assets for specific products or services along with legal assistance to register trademarks, and recurring indirect costs - e.g. to keep protecting a brand asset over time a firm must prove that the specific asset is actively in use in a defined market 
segment for consecutive years and pay trademark renewal fees (Giarratana and Torrisi, 2010). Furthermore, similar to other intellectual property rights (IPRs), even if a brand asset is protected with a trademark, actual enforcement can be costly-both in terms of direct legal costs and in terms of indirect business costs of litigation. In light of such observations, small companies, and technology ventures in particular, should face in principle significant constraints in their ability to develop brand assets and protect them with trademarks.

Research on brand development strategies in start-ups and young ventures is limited. Inductive studies addressing the issue have shown that entrepreneurs seem to be the major driving actors in this process and that they value the use of trademarks to protect brand assets such as a name, a logo, a color palette, and other visual and non-visual elements (Bresciani and Eppler, 2010; Rode and Vallaster, 2005). No study so far has examined the role of active investors in this process. In particular, VC funding represents a key transition in the lifecycle of technology ventures. Yet, it is not clear to what extent VC backing impacts the development of brand strategies.

\section{HYPOTHESES}

\section{VC Backing and the Development of Brand Assets}

Research on the effects of VC funding in young technology ventures shows that, beyond a transfer of financial resources, VC firms help to shape both the R\&D and commercialization 
strategies of investee firms (Bertoni, Colombo, and Grilli, 2011; Boeker and Wiltbank, 2005; Engel and Keilbach, 2007; Fitza et al., 2009; Hsu, 2006).

On the one hand, VCs can intuitively provide funding that helps technology ventures to meet the direct and indirect costs of brand asset development. These include hiring a design firm to develop brand assets, the fees associated with filing trademark applications, the opportunity cost of time devoted to the filing process, as well as other expenses, such as contracting legal services to understand trademarking rules and filing procedures to file a trademark application for multiple classes of goods or services, to file a statement of use, and to demonstrate a brand asset's commercial use (Ramello and Silva, 2006).

On the other hand, VCs also provide valuable feedback on strategic planning in a period of the life of technology ventures in which they generally lack business development capabilities (Boeker and Wiltbank, 2005; Fitza et al., 2009). In particular, the effective development and deployment of brand assets is a critical issue for new technology ventures, because founders often have science/technological backgrounds with competences mainly related to R\&D rather than commercialization (Rindova et al., 2012). Firms must sustain considerable efforts to understand which and how many different brand assets to develop and VC backing has been shown to foster product ramp up and launch (Krishnan and Ulrich, 2001). Hence, we argue, VCs will have an incentive to foster the development of brand assets in new technology ventures by leveraging their accumulated experience with other early stage startups to transfer tacit knowledge about potential customers' needs (Hsu 2006) and about the benefits and drawbacks of alternative brand strategies and brand extension opportunities, effectively mitigating technology ventures' learning cost. 
In addition, by participating in strategy setting and facilitating the professionalization of the firm (Fitza et al., 2009; Hellmann and Puri, 2002) ${ }^{4}$, VCs have an incentive to foster new ventures to reach business development milestones — such as product development and the preparation of marketing plans. We thus argue that VCs will spur portfolio companies to create actionable commercialization strategies for specific products and services and to develop brand assets to identify and differentiate such offerings.

Moreover, VCs usually rely on staged capital infusion mechanisms to alleviate the information asymmetry problem and reduce the investment risks (Gompers and Lerner, 2001; Munari and Toschi, 2015). The brand assets that technology ventures can protect via trademarks are intangibles created for specific products and services which can play a role in VCs subsequent funding decisions. For example, brand assets are typically created before launching a new product and often serve as predictive cues of product performance to consumers (Krasnikov et al., 2009). Also, developing brand assets can contribute to increase the visibility of portfolio companies to external audiences offering signals to potential partners with which to engage in cooperative commercialization strategies (Hsu, 2006). In line with this view, recent evidence suggests that VCs can set the development of brand assets and related trademarks as a condition to receive subsequent rounds of funding and that the presence and number of trademarks in new ventures relates positively to their valuation (Block et al., 2014b).

\footnotetext{
4 VCs' involvement has been shown for example to help in recruiting scientific personnel that in turn enhances startups' innovative output (Arqué-Castells, 2012) and to improve firms' human resource management and corporate governance structures (Hsu, 2006).
} 
In sum, it is reasonable to expect that upon receiving VC funding, startups will increase their efforts to build specific brand assets to commercialize future products and to file trademarks to protect them. Accordingly, we propose the following hypothesis:

\section{H1: VC backing increases the number of brand assets for which technology ventures seek trademark protection.}

\section{VC Backing and the Scope of Brand Assets}

The positive and negative aspects of diversification decisions are a central concern of the strategy field. Drawing on a central tenet of the resource-based view - i.e. that firms diversify in order to leverage firm-specific resources (Barney, Ketchen, and Wright, 2011), we argue that a dimension of brand strategy which is likely to be affected by VC backing is the ability of investee companies to leverage brand assets for efficient diversification.

Most firm resources are subject to opportunity costs, facing limits in the number of activities in which they can be redeployed (Ref and Shapira, 2017; Wu, 2013), but brand assets are scale free resources - i.e. do not face limits in the number of activities in which they can be concurrently redeployed (Levinthal and Wu, 2010; Sakhartov and Folta, 2014; Sakhartov and Folta 2014).

Technology ventures often feel the urge to develop diverse portfolios of products with multiple features and variants (Andries, Debackere, and van Looy, 2013; Fernhaber and Patel, 2012). The use of a common brand asset to market different types of products can induce economies of scope in both R\&D and marketing, facilitating the acquisition of capital (Wry et al., 2014) as well as specialist personnel (Ramello and Silva, 2006). 
We argue that VC backing may be particularly valuable for technology ventures which are evaluating diversification opportunities. In particular, choices about whether to focus on exploration — to try to realize an innovation's full potential—or whether to focus on exploitation - to ensure the commercial success of a limited number of products based on a particular application of their technology platform (Choi, Lévesque, and Shepherd, 2008; Kotha, Zheng, and George, 2011). These are critical decisions in the early years of technology ventures often because the capabilities firms need to exploit opportunities differ from the skills required to identify them (Hitt et al., 2001; Ketchen, Ireland, and Snow, 2007). Moreover, these are choices managers face in the organization of activities across both their organizations' functional domains of R\&D and marketing (Slotegraaf and Atuahene-Gima, $2011)^{5}$. Targeting multiple product markets with different brand assets can thus impact the internal organizational structure and reduce the scope for synergies across departments ${ }^{6}$.

VCs have a direct interest to help investees discover new applications of their technologies with high potential returns, but are also interested in their effectual conversion into commercial products. Leveraging a common brand asset across different product-market categories can allow a young technology venture to concentrate limited resources on the development of product lines - signalling a viable pipeline of future applications of its technology to external

\footnotetext{
${ }^{5}$ Technology ventures are characterized by highly uncertain outcomes. Especially when they operate in nascent industries (Ott, Eisenhardt, and Bingham, 2017) and try to develop and commercialize potential applications of a general purpose technology (Grodal, 2018) firms face trade-offs between depth and breadth in their objectives (Ambos and Birkinshaw, 2010). Without knowing ex ante the ultimate payoff associated with a particular commercial application of the technology, they can experiment by pursuing multiple parallel objectives. However, as the number of R\&D and marketing objectives increases, the marginal cost of adding an objective increases and the organization and coordination of R\&D and marketing activities becomes more difficult (Leiponen and Helfat, 2009).

${ }^{6}$ Simulation studies show that firms undergoing reorganization miss more opportunities relative to those that are not reorganizing, lowering resources and increasing their hazard of mortality (Hannan, Pólos, and Carroll, 2003).
} 
audiences (Block et al., 2014b) —while it is busy doing the groundwork for launching a first product or service to generate revenues (Klingebiel, 2012). Besides sales growth opportunities, external audiences, such as new potential investors can value a diversified product portfolio, thanks to its ability to "bundle" startups' resources — making imitation from competitors more difficult. However, decreasing returns from product portfolio complexity call into question its true value (Fernhaber and Patel, 2012).

Diversification is often a risky strategy for resource constrained startups (e.g., Ching, Gans, and Stern, 2017; Huckman and Zinner, 2008). Focus and tight coupling between R\&D and marketing is often required because the coordination costs generated by decoupling upstream R\&D and downstream marketing activities can increase risks and delay much needed revenues from one first launched product. Most resources a young startup controls, such as production capacity and managerial time and attention, are non-scale free, so that their use in one market usually precludes their use in other settings (Levinthal and Wu, 2010; Ref and Shapira, 2017). Accordingly, research often suggests that young technology ventures should commit to one major application of a technology and resist diversification until a first major application of their technology is launched and starts to generate revenues (Burgelman and Grove, 2007; Posen and Levinthal, 2012).

By enlarging a brand asset's scope, a technology venture can however effectively "option" multiple commercial applications of a common underlying technology to be marketed under a common brand asset without major commitments and impacts on a firm's operations ${ }^{7}$. By developing brand assets that can be leveraged across different products a young firm can thus

\footnotetext{
7 Trademark applications with more than one class of goods or services are usually subject to additional fees for each additional class, but the marginal contribution of additional classes on the baseline costs that a firm needs to face to file a trademark is likely to be modest.
} 
secure space for future growth of a product line without actually diversifying both R\&D and marketing activities right away. VC firms place emphasis on the pursuit of diversification strategies that make efficient use of scale free resources, such as brand assets and patents (Samila and Sorenson, 2010). We thus expect that VC backed startups will be more likely to develop brand assets that can be used across multiple different product-markets resulting in trademarks with wider scope. We therefore propose the following hypothesis:

\section{H2: VC backing increases brand asset scope, defined as the number of different} market categories that a company can target with the same brand asset.

In summary, we draw on resource-based view arguments to argue that brand assets are important scale free resources in the context of technology ventures and that VC backing can act as catalyst to develop such resources. In particular, we theorize that after receiving VC funding firms will create more brand assets and will develop brand assets that can be used across multiple different product-market categories.

\section{METHODS}

\section{Empirical Setting: The UK Micro- and Nano-technology Sector}

The context of our study is the population of technology ventures operating in the micro- and nano-technology (MNT) sector in the United Kingdom ${ }^{8}$. Some unique features of this setting are particularly appropriate to test our hypotheses on the impact of $\mathrm{VC}$ backing on the brand strategies of technology ventures.

\footnotetext{
${ }^{8}$ The MNT sector is characterized by "the design, characterization, production, and application of structures, devices, and systems by controlled manipulation of size and shape at the nanometer scale [...] that produces structures, devices, and systems with at least one novel/superior characteristic or property" (Bawa et al., 2005).
} 
First, brand strategy is particularly important in nascent industries where symbolic boundaries are evolving and the MNT industry in the observed period is a prime example of a context where social and symbolic boundaries periodically expand and contract (Granqvist et al., 2013; Grodal, 2018). In the MNT industry the symbolic boundaries are particularly affected by the fact that the prefix "nano" is often misused for marketing purposes of "non-nano" products. In the contested, evolving MNT field, brand assets are therefore crucial for new technology venture to operate because peripheral actors may claim membership in the field and dilute opportunities for differentiation (Granqvist et al., 2013; Grodal, 2018). The MNT industry also offers a test of our arguments in a context where brand assets do matter, but that is clearly technology driven and manufacturing intensive - as opposed to other industries that are focused on using new technologies for the development of services that rely on sizeable user bases and ad-supported business models.

Second, brand assets are important scale free resources in the MNT sector which can become useful for diversification decisions (Sakhartov and Folta, 2014). Specifically, the MNT sector is characterized by general purpose technologies that can be leveraged across a variety of technology applications that, in turn, can be embedded into different product artifacts. This presents new technology ventures with dilemmas on whether to diversify or not into different product-markets, how many brand assets to develop, and whether to leverage a brand asset across multiple product categories and product lines.

Finally, the UK market is second only to the US one for what concerns the development of the VC industry (Lockett, Murray, and Wright, 2002) and the UK MNT sector has been characterized by a significant growth over the last two decades, largely driven by the 
emergence of innovative start-ups and the infusion of equity by VC funds (Munari and Toschi, 2014).

\section{Sample and Data Sources}

We constructed our dataset in six steps. First, we identified the population of startups operating in the UK MNT sector using the Industrial Map of UK MNT ${ }^{9}$. From this source, we identified 193 new ventures founded from 1996 and recovered detailed information such as the founding year, the registered address and a brief company description. Second, we used Companies House ${ }^{10}$ to recover all the names used by each startup to check for name changes and statuses. Third, we used Thomson One to check whether a startup received VC backing or not, and to collect additional information such as the date of the first round of $\mathrm{VC}$ financing. Fourth, brand assets are univocally linked to trademarks and previous research shows the reliability of trademark data to track firm efforts to develop brand assets (Block, Fisch, and Sandner, 2014a; Flikkema et al., 2014; Krasnikov et al., 2009). To capture the branding activities of startups we collected all trademarks registered by the companies in our sample from the UK Intellectual Property Office and the EU Office for the Harmonization of Internal Markets (OHIM).

Fifth, we collected data on the directors of each startup from Bureau van Dijk FAME, a database containing comprehensive economic and legal information on companies in the UK

\footnotetext{
9 An exhaustive map of the sector compiled in 2004 by the MNT Network in association with the UK Department of Trade and Industry (DTI)

10 The official UK Government register, including information on all limited companies in England, Wales, Northern Ireland and Scotland.
} 
and Ireland. For each firm we collected the current and previous list of directors and for each director the title, appointment date, resignation date, and birth date. We also used the database Company Director Check in order to collect information on each director's previous work experience and specific roles as directors in other firms.

Sixth, we used Lexis Nexis and Orbit to collect, respectively, media articles mentioning the firms and worldwide patent applications and patent citation data.

Our final dataset is an unbalanced panel on 192 startups $^{11}$ established from 1996, including 67 VC-backed (around 35\% of our sample) and 125 non-VC-backed startups. 70 startups ( $36 \%$ of our sample) filed at least one trademark during the observation period.

\section{Dependent Variables}

We characterize the branding activities of startups in terms of the number of brands and the scope of brands. The variable Number of Brand Assets B $_{i t}$ captures the number of brand assets for which a firm seeks trademark protection in each year $t$. It is measured as the number of trademark applications filed by company $i$ in year $t$. The variable Brand Asset Scope ${ }_{i t}$ captures the extent to which a technology venture leverages a single brand asset across multiple different product-market categories. It is measured by the total number of different NICE classes on all the trademarks filed by the focal startup in year $t$, as trademarks with a broader scope tend to protect brand assets used to market different kinds of products or wider product lines. When filing a trademark, the applicant and examiners will define the scope of application of a trademark using the NICE classification of goods and services. This taxonomy indicates

11 By searching all the names ever used by each startup in Thomson One, we identified 9 additional startups not included in the Industrial Map of UK MNT, but we excluded 10 startups not covered by FAME. Therefore, our final sample includes 192 firms. 
the scope of a brand asset by specifying a limited set of market segments in which the legal protection of a trademark is valid. The goods and services to which a registered trademark applies are classified in the same way in all countries that have adopted the NICE Classification. We use filing rather than registration date to minimize the lags between trademarking decisions and firms' internal deliberations about brand strategies.

\section{Explanatory Variable}

VC Backing ${ }_{i t}$ measures whether the firms in our sample received or not VC funding. It is operationalized as a dummy taking value 1 for VC-backed startups from the year of first round of $\mathrm{VC}$ funding onwards, and zero otherwise ${ }^{12}$.

\section{Control Variables}

The composition of the top management teams of technology ventures and the backgrounds of team members affect firms' growth trajectories (Sine, Mitsuhashi, and Kirsch, 2006). In particular, a long tradition of studies shows that the education levels of firms' directors have a positive impact on capability development and innovative outputs (e.g., Johnson, Hoskisson, and Hitt, 1993), but directors with extensive experience in the R\&D realm might be less well versed in the marketing one. The top management team of new technology ventures often is populated by individuals with science/technological backgrounds with competences mainly related to R\&D rather than marketing and commercialization (Rindova et al., 2012). To capture this trait, the dummy variable $T M T P h D_{i t}$ takes value 1 if any director of the focal

${ }^{12}$ Our operationalization follows recent research on VC-backed firms showing that the effects of VC-backing persists over time (Croce et al., 2013). 
startup in a given year has a $\mathrm{PhD}$ title. Furthermore, other elements related to human capital, such as prior experience as directors in other firms, are likely to positively influence the ability of the top management team to strengthen startups' downstream marketing activities (Beckman, Burton, and O'Reilly, 2007). TMT Experience ${ }_{i t}$ is a dummy variable taking value 1 if any director of the focal firm in a given year has had prior directorship experience in other firms. Similarly, management teams that include directors with previous experience in the marketing and/or legal function may affect the marketing strategy pursued by a technology venture (Germann, Ebbes, and Grewal, 2015). We include the variable TMT Marketing or Legal to control for directors that before joining the firm accumulated experience in occupations affiliated with either the legal or marketing function ${ }^{13}$. Moreover, old directors and young directors bring to the top management team of technology ventures heterogeneous experiences that are likely to shape their attitudes and values. Since diversity of attitudes and values facilitates creativity (Tortoriello, McEvily, and Krackhardt, 2015) we expect that heterogeneity among company directors' age will positively impact a startup's ability to develop commercialization strategies and related brand assets. We thus computed a variable TMT Age Disparity ${ }_{i t}$ by dividing directors into 5 groups with respect to their ages: directors with ages between 20 and 30; ages between 31 and 40; ages between 41 and 50; ages between 51 and 60; and ages older than 60. Then age disparity is calculated with the following formula (Bantel and Jackson, 1989): TMT Age Disparity $=1-\Sigma \mathrm{p}_{i}^{2}$ where $\mathrm{p}$ represents the proportion of team members in each of the five age categories and $i$ denotes each category.

\footnotetext{
13 We thank an anonymous reviewer for this insightful suggestion.
} 
We control for Firm Innovative Productivity because technology venture with better innovative output may be more likely to embed applications of their technologies in product artifacts and to create brand assets to market them as products or services. Patent counts have been extensively used as a proxy for inventions. However, research on innovative productivity recommends to accounts for differences in the quality of the underlying innovations that are protected by a stock of patents because highly cited patents typically have a higher commercial value (Aggarwal and Hsu, 2014). Therefore, similar to other studies, we measure a firm's innovative productivity using a firm's citation-weighted patent stock (Bertoni and Tykvová, 2015). The variable Firm Age ${ }_{i t}$ measures the age of all the firms in our sample in each year $\mathrm{t}$ since the founding year.

To control for potential unobserved factors related to business and technological cycle, we include a set of Year fixed effects. Similarly, we include a set of Region fixed effects to capture potential factors tied to the geographic location of each company, such as positive and negative spillovers and local networks that can influence resource acquisition (Agarwal, Audretsch, and Sarkar, 2010). Table 1 provides a summary of all variables and data sources. Table 2 presents descriptive statistics and the correlation matrix for all the variables used in our study and does not indicate multicollinearity issues.

Table 1 and Table 2 about here

\section{ANALYSIS AND RESULTS}

We investigate a technology venture's brand strategy as a function of VC funding by studying all the technology ventures operating in the micro- and nano-technology (MNT) sector in the United Kingdom. Given the longitudinal nature of our data, we estimate different regression 
models using panel approaches to study the effect of our main explanatory variable $-V C$ backing — on Number of Brand Assets and Brand Asset Scope.

Table 3 reports all our regression results. As our dependent variables involve count data, we estimate all the models using a panel negative binomial estimator in STATA. To choose between fixed and random effect models we run a Hausman test which indicates that a random effect specification is appropriate.

Table 3 about here

Column 1 shows a positive and statistically significant effect of VC Funding on the Number of Brand Assets created by our sample of technology ventures. A similar pattern emerges from the estimates of the effects on Brand Asset Scope (Column 2). The coefficients of the variable VC backing are all positive and statistically significant $(\mathrm{p}<0.05)$. These results thus support $\mathrm{H} 1-$ showing a positive effect of VC backing on the number of brand assets for which firms seek trademark protection - and $\mathrm{H} 2$ - showing that after receiving $\mathrm{VC}$ funding firms tend to file trademarks with a broader scope to market different types of products and services with a common brand asset. We also included controls for region-, and year-specific factors (e.g. proximity to sources of positive or negative spillovers, aggregate time trends) and note, as expected, a significant and positive effect of year 1996 on both the number of brand assets and brand asset scope ${ }^{14}$. Overall, the results reported in columns 1 and 2 support our hypotheses, suggesting that VC backing is positively associated with both an increase in the number of brand assets as well as the use of a common brand asset for different products and services. We recognize, however, that VCs select which ventures to invest in. Accordingly, in subsequent

14 The Community Trademark application system was introduced after the Madrid Agreement came into operation on 1 April 1996. 
analyses, we aim to assess whether and to what extent our results are affected by possible selection issues associated with differences in firms' characteristics.

\section{Coarsened Exact Matching}

We begin to address the impacts of unobserved selection into VC-funding by using a matching approach to identify similar control firms (i.e. non-VC-backed ventures) for each VC-backed venture. Like several other scholars, we implement a coarsened exact matching (CEM) approach to reduce imbalance in observable differences between treated and control groups (e.g., Aggarwal and Hsu, 2014; De Figueiredo, Meyer-Doyle, and Rawley, 2013; Singh and Agrawal, 2011) ${ }^{15}$. Consistent with previous research on technology ventures, we matched firms by selecting innovative productivity, founding year, and geographical location as matching criteria (Aggarwal and Hsu, 2014; Fitza et al., 2009; Hsu, 2006; Pahnke, Katila, and Eisenhardt, 2015).

Innovative productivity is an important matching criterion because VCs are more likely to consider funding technology ventures that also own a strong patent portfolio (Bertoni et al., 2011; Pahnke et al., 2015). As the quality of patented technologies varies, with highly cited patents typically resulting in a higher commercial value (Aggarwal and Hsu, 2014) and increased likelihood of product approvals (Pahnke et al., 2015), we account for differences in the quality of the underlying innovations by matching firms based on their citation-weighted patents (Bertoni and Tykvová, 2015). Similarly, matching firms based on the same founding

\footnotetext{
15 We thank an anonymous reviewer for this suggestion. We opt for coarsened exact matching (CEM) instead of propensity score matching (PSM) because recent research shows that CEM is likely to produce more balanced matched samples than PSM (Iacus, King, and Porro, 2011; Iacus et al., 2012).
} 
year is important because the availability of capital and opportunities is subject to year-to-year variations that may substantially affect the evolution of new technology ventures (Bertoni, D'Adda, and Grilli, 2018). Finally, matching firms based on geographical location is important because opportunities are typically localized, as VCs have a preference to fund firms within geographical areas that allow frequent interaction and monitoring (Hsu, 2006; Pahnke et al., 2015). Also, different VC markets may be more or less thin in terms of participants, so that opportunities to be funded may depend on the regional availability of funding (Bertoni et al., 2018). Similarly, geographical locations differ in the availability of complementary assets and opportunities for knowledge exchange (e.g. nanotechnology ventures founded in Scotland may benefit from their proximity with the nano-materials cluster that emerged around the University of Manchester).

Firms that create brand assets and protect them using trademarks could differ in unobservable ways from firms that do not, such as in the quality of their underlying products and technologies, leading to a higher probability to receive VC funding. Matching allows to address differences between firms by selecting a subsample from the data where the treated (VC-backed firms) and control groups (non-VC-backed firms) are balanced with respect to the matching criteria. This involves a trade-off between how strict is the similarity between matches and the likelihood that a match can be found. CEM identifies matches by temporarily coarsening each matching variable into substantively meaningful "bins", exact matching within each bin, and then retaining the uncoarsened values of the matched data for estimating the effect of VC funding (Iacus, King, and Porro, 2012). 
Following Blackwell and colleagues (2009), we began our matching procedure by assessing the imbalance in covariates between VC-backed and non-VC-backed firms in our original sample (Multivariate L1 distance: 0.86 ). We then considered several coarsening alternatives to minimize the imbalance. Like prior work (Hsu, 2006; Pahnke et al., 2015), we first attempted to find non-VC-backed firms that matched exactly on each criterion. If we could not identify an exact match, we first relaxed the non-treated firm's founding year to match the year before or after that of the treated firm. If there was still no match, we relaxed the citation-weighted patents to be within one of the focal firm ${ }^{16}$, and then the geographical region to nearby regions in the same country in the UK. The CEM subsample resulting from this coarsening strategy shows a substantially lower imbalance in covariates between VC-backed and non-VC-backed firms (Multivariate L1 distance after CEM: 0.36).

We finally use the CEM sample to estimate negative binomial models which include the un-coarsened values of the matching variables to account for any remaining imbalance (Blackwell et al., 2009). The estimates obtained from the CEM sample are reported in columns 3 and 4 of Table 3 and confirm the results reported in columns 1 and 2: VC funding is positively associated with an increase in both the number of brand assets for which firms seek trademark protection and the scope of those brand assets.

\section{An Alternative Approach Exploiting Media Sentiment}

To further probe the robustness of our results we attempt to account for selection into $\mathrm{VC}$ funding with an instrumental variable approach. We considered using an instrument that leverages the local availability of the selected characteristic (e.g., Alvarez-Garrido and

\footnotetext{
16 If the focal firm did not patent we find a match only among other non-patenting firms (Pahnke et al., 2015).
} 
Dushnitsky, 2016; Samila and Sorenson, 2010), which in our context would be the local supply of venture capital in the UK micro- and nano-technology industry, but these data were not available. As an alternative approach, we build on recent research on the effects of media sentiment about a venture on VCs investments decisions (Aggarwal and Singh, 2013) that suggest that the relative amount of favorable media coverage of a startup before VC funding can provide a theoretically useful instrument. Consistent with previous studies, we measure the variable Media Sentiment using the coefficient of media favorableness (Aggarwal and Singh, 2013; Deephouse, 2000):

$$
\text { Media Sentiment }= \begin{cases}\left(\mathrm{f}^{2}-\mathrm{fu}\right) /(\text { total })^{2} & \text { if } \mathrm{f}>u \\ 0 & \text { if } \mathrm{f}=\mathrm{u} \\ \left(\mathrm{fu}-\mathrm{u}^{2}\right) /(\text { total })^{2} & \text { if } \mathrm{u}>f\end{cases}
$$

where "f" is the stock of favorable news; " $\mathrm{u}$ " is the stock of unfavorable news; "total" is the stock of total news. This a continuous variable which ranges between -1 and 1 , with 0 indicating neutral sentiment ${ }^{17}$.

The intuition for the instrument is as follows. Consider two different firms, one that receives relatively more favourable media coverage (i.e. media sentiment closer to 1) and another that receives relatively more negative media coverage (i.e. media sentiment closer to -1). Recent research shows that firms with relatively more positive media sentiment are more likely to be considered for funding (Aggarwal and Singh, 2013; Bajo and Raimondo, 2017). While the actual matching of VCs and ventures may be endogenous, a technology venture's

\footnotetext{
${ }^{17}$ We used Lexis-Nexis to gather information on the coverage in the media of the ventures included in our sample. We coded an article as favorable if it praised the startup for its actions or involvement in some events that may increase its reputation, such as receiving an award for its technology; we coded an article as unfavorable if it criticized the startup for its actions or involvement in some events that may decrease its reputation, such as massive layoffs; and we coded an article as neutral if there were no positive or negative evaluations about the firm.
} 
media sentiment (i.e. the combination of positive and negative media reporting about the venture) is exogenous. Therefore, the instrument meets both the relevance and the exclusion restriction criteria. Recall that the aspects of a firm's brand strategy that we focus on our study are the quantity of different brand assets ${ }^{18}$ and the use of a common brand asset across different product categories. It is important to note that brand assets are symbols which can be protected via trademarks for use on a well-defined set of artifacts types in one or more product-markets. The creation of specific artifacts and brand assets and their use in more or less product-markets is therefore not likely to be directly affected by our instrument (media sentiment). Media sentiment before VC funding is not an antecedent of these specific outcomes of brand strategy, but it is positively associated with the likelihood of receiving VC funding. Hence, Media Sentiment can offer a suitable instrument to address venture selection into $\mathrm{VC}$ funding.

Our dependent variables take only integer, nonnegative values. Accordingly, we estimate a two-stage residual inclusion (2SRI) model, which incorporates the residuals of the first stage as an additional regressor in the second stage, using bootstrap to correct the standard error (Alvarez-Garrido and Dushnitsky, 2016; Wooldridge, 2002) ${ }^{19}$. After each iteration, the estimates are stored and the process is repeated 1000 times, which is well above the 768 repetitions recommended by Andrews and Buchinsky (2000) as minimum number of bootstrap replications.

\footnotetext{
18 The European Union allows to register trademarks for the following six types of brand assets: word mark, represented using words, letters, numbers or any other characters that can be typed; figurative mark, represented using pictures, graphics or images; figurative mark containing letters, combines the use of pictures, graphics or images with words or letters; three-dimensional mark, represented using a three-dimensional shape, such as the actual product or its packaging; colour per se mark, used only to register an actual colour to distinguish products or services; sound mark, represented graphically using musical notation k (EUIPO, 2017).

19 We thank an anonymous reviewer for this suggestion.
} 
Table 3 reports the second-stage 2SRI results in columns 5 and 6 while the results of the first stage model are reported in column 7. Results show that Media Sentiment is positively associated with the likelihood of receiving VC funding (Table 3, column 7) while the estimates reported in columns 5 and 6 support the results reported in columns 1 to 4 s. For the effect of VC-backing on the Number of Brand Assets, the coefficient of VC-backing is consistently significant $(\mathrm{p}<0.05)$ with the expected sign. The effect of VC backing on Brand Asset Scope is also confirmed ${ }^{20}$.

Finally, one might worry that differences in brand assets that are protected via trademarks reflect not specific brand strategies, but rather an increased interest in signalling unobservable firm quality to external audiences with property rights. Research shows that trademarks can boosts VC valuations (Block et al., 2014). In would-be-VC-backed companies this could increase the tendency of entrepreneurs to file trademarks for signalling purposes rather than actual branding efforts. One way to rule out this source of endogeneity is to see whether the surge in trademark occurs before VC funding, which could suggest that a company begins to plan for VC in advance and may attempt to boost its valuation and likelihood of funding by signalling ownership of IPRs ${ }^{21}$.

Figure 1 illustrates the total number of trademark filings and the number of start-ups trademarking before and after receiving VC funding to appreciate the differences, supporting

\footnotetext{
20 Results remain virtually unchanged also when estimating equivalent regressions using Poisson models. As an alternative specification we also estimated a panel two stages-least squares fixed effect IV model taking the natural logarithm of our dependent variables. Post estimation IV diagnostics indicate that Media Sentiment is a suitable instrument for VC-backing as the Cragg-Donald F-statistic of 45.04 exceeds the Stock and Yogo (Stock and Yogo, 2002) critical value for instrument strength (16.38 at 10\% bias).

${ }^{21}$ We thank an anonymous reviewer for this suggestion.
} 
the argument that a surge in trademarking for VC backed companies occurs after the receipt of VC funding, not before.

Figure 1 about here

In conclusion, the results of the main analyses and the robustness tests are broadly suggestive that our proposed hypotheses are confirmed.

\section{DISCUSSION AND CONCLUSIONS}

Resource-based approaches to the study of entrepreneurship regard brands as important scale-free resources enabling firm growth and competitive advantage (Barney et al., 2011; Levinthal and $\mathrm{Wu}, 2010$; Wernerfelt, 1984; $\mathrm{Wu}, 2013)$. Research on venture capital shows that VC backing can enhance startups' growth trajectories along various dimensions, with particular attention to innovation (e.g. Lahr and Mina, 2016; Sørensen, 2007). Yet it falls short in explaining whether and how VCs affect the development of brand strategies in technology ventures. To our knowledge, our study is the first to contribute theory and evidence on the effects of VC backing on startups' development of brand assets. We construct a firm-year panel data set of all the nanotechnology startups in the UK, VC-funded and non-VC-funded, and track these firms from 1996 through the end of 2011. We measure the outcomes of their branding efforts using trademark filings as proxies for the brand assets they create.

We find that investee companies create more brand assets after receiving VC backing. We also find that, after receiving VC backing, firms increasingly develop brand assets with a wider scope that can be used across multiple different product markets. Our findings are robust to alternative specifications addressing selection into VC funding. 
Although the results of this study should be interpreted with caution, they contribute in major ways to the ongoing conversation on the effects of $\mathrm{VC}$ backing on portfolio companies and current perspectives on scale free resources in technology and innovation management.

Our first major contribution is to research investigating the importance of VCs for startups' growth trajectories. The role of VC backing in supporting innovative productivity has been extensively documented (e.g., Fitza et al., 2009; Hellmann and Puri, 2002; Hsu, 2006; Lahr and Mina, 2016). In contrast, we offer new theory and evidence on how VCs affect the way startups build and deploy brand assets for the commercialization of products and services. Our finding that $\mathrm{VC}$ backing is positively associated with an increase in the number of brand assets is relevant to both start-up entrepreneurs and managers at VC firms because brands often serve as important predictive cues of product performance to consumers (Krasnikov et al., 2009) and can help firms appropriating the returns on innovation beyond patent expiration (Ramello and Silva, 2006).

Second, highlighting VCs' role in the scope of technology ventures' branding initiatives we also contribute to those studies that have highlighted the importance of scale free resources (Levinthal and $\mathrm{Wu}, 2010$; $\mathrm{Wu}, 2013$ ) and downstream marketing activities (Chandy et al., 2006; Morgan et al., 2009) to convert promising innovations into sought-after products. Our finding that VC backing is associated with increases in the scope of brand assets, suggests that VC-backing affects startups' strategic decisions about product market combinations as reflected in brand assets with a broad scope, which can support potential brand extensions. After VC funding, technology ventures seem more oriented towards "optioning” multiple applications of their technology to be marketed using a common brand asset. The advantages, 
disadvantages, and timing of diversification have been extensively studied by entrepreneurship scholars concerned with technology commercialization strategy (Katila, Chen, and Piezunka, 2012; Marx et al., 2014). In particular, whether and when to develop diverse portfolios of products with multiple features and variants is a pressing issue for technology ventures (Andries et al., 2013; Fernhaber and Patel, 2012). The creation of brand assets with a scope large enough to market different types of products can favor economies of scope in both R\&D and marketing because, unlike most firm resources, brand assets do not face opportunity costs and clear limits in the number of activities in which they can be redeployed (Ref and Shapira, 2017). Brand assets and the degree to which they are fungible across product markets can thus favour synergies in technology ventures' diversification decisions (Levinthal and $\mathrm{Wu}, 2010$; $\mathrm{Wu}, 2013)$.

Previous research shows that VC funding accelerates the creation of marketing roles and the appointment a VP of Sales and Marketing (Hellmann and Puri, 2002) leading to faster time-to-market (Hellmann and Puri, 2000). The effects of VC backing we document is relevant for both managers at startups and VC firms alike because companies that deploy brand assets early on have been shown to be approximately 5 times more likely to achieve an IPO or acquisition outcome within 6 years of founding (Guzman and Stern, 2015). Finally, a longstanding debate among entrepreneurship scholars is whether patents are a good proxy for the upstream side of innovative performance - the creation of inventions - , but less good at capturing the downstream side of innovative performance- the commercialization of products and services. We offer novel methodological insights to the growing stream of literature that is focusing on trademarks to characterize the downstream market-related 
activities of firms (Block et al., 2014b, 2014a; Flikkema et al., 2014; Mendonça et al., 2004). Our focus on VCs extends this stream of research by identifying how VC backing shapes the development of brand assets, as measured by trademark filings. We believe the impact of VC backing on the strategic use of different IPR mechanisms in new ventures, such as trademarks and copyrights, is an issue that deserves further inquiry by future research. We make a first step in this direction by leveraging trademark data as a proxy for technology ventures' branding activities.

Our research has some limitations that can be investigated by future researches. First, while using data from a single sector — micro and nanotechnology — ensures internal validity, caution should be applied in generalizing our results to other sectors, especially less technology intensive sectors or other sectors where the incentives for the creation of brand assets may differ. Second, we studied the impact of VC backing on the brand strategy of technology ventures. However, we do not know the impact of the amount of $\mathrm{VC}$ funds startups received on their subsequent trademarking activities. In addition, our results indicate that VC backing is associated with the development of brand assets, but we still know little about the specific organizational mechanisms through which VC involvement affects technology ventures' brand strategies, such as what specific activities they undertake, whether different types of investment syndicates lead to different brand strategies, the potential impacts of different types of exits, and whether different institutional environments will affect the ability of VC to support investee companies to develop brands. These represent potentially interesting avenues for further research in this area. 


\section{Implications for Practice}

We believe that our study has important implications for the development of brand assets in nascent industries where symbolic boundaries are evolving. In particular, the context of our study is the nanotechnology industry, which has been described as a prime example of a nascent industry where social and symbolic boundaries periodically expand and contract (Granqvist, Grodal, and Woolley, 2013; Grodal, 2018). Decisions about the development of brand assets and their scope can be particularly important in such industries. First, in the contested, evolving nanotechnology field, symbolic boundaries are particularly affected by the misuse of the prefix "nano" for marketing purposes of non-nanotechnology products (Grodal, 2018). Brand assets are therefore crucial for new technology ventures to operate because competitors can claim membership in the field and dilute opportunities for differentiation.

Second, nanotechnology is a general-purpose technology with applications in a wide variety of domains (Grodal, 2018). Previous research has shown that effectively developing and deploying brand assets is crucial for firms commercializing general-purpose technologies not only to differentiate their offerings in consumer and/or business markets, but also to access downstream complementary resources through alliances or partnerships (Lee, Struben, and Bingham, 2018). General purpose technologies present major value creation opportunities, often associated with the emergence of entirely new markets. Yet, converting innovations into technological applications and successfully embodying such technologies in commercial products poses significant and unique challenges to entrepreneurial firms due to high levels of both technological and market uncertainty within and across multiple conversion trajectories, corresponding to the different potential applications of a general-purpose technology 
(Eisenhardt and Bingham, 2017; Ott, Eisenhardt, and Bingham, 2017). Our study suggests that the scope of brand assets can become an important strategic decision for such entrepreneurial firms. By developing brand assets that can be leveraged across different products an entrepreneurial firm can secure space for future expansion of its product portfolio without actually diversifying right away. In other words, by enlarging a brand asset's scope, a firm can "option" multiple commercial applications of a common underlying technology to be marketed under a common brand without major commitments and impacts on a firm's operations. We believe that exploring the link between the scope of brand assets and diversification decisions in entrepreneurial ventures represents a fruitful avenue for further research in this area.

\section{Acknowledgements}

The authors are particularly grateful to Professor Mike Wright, the associate editor, and the three anonymous referees for providing constructive and developmental assistance throughout the review process. The authors appreciate helpful comments from colleagues at UCL School of Management, Columbia Business School, Cass Business School, Copenhagen Business School, and seminar participants at the Academy of Management Annual Meeting and DRUID. Part of the work was performed while the last author received financial support under the Erasmus Mundus fellowship and the Youth Project of Humanities and Social Sciences Research of the Chinese Ministry of Education (Grant \# 17YJC630207). The usual disclaimer applies. 


\section{REFERENCES}

Agarwal R, Audretsch D, Sarkar M. 2010. Knowledge spillovers and strategic entrepreneurship. Strategic Entrepreneurship Journal. John Wiley \& Sons, Ltd. 4(4): 271-283. Available at: http://doi.wiley.com/10.1002/sej.96.

Aggarwal R, Singh H. 2013. Differential Influence of Blogs Across Different Stages of Decision Making: The Case of Venture Capitalists. Management Information Systems Quarterly 37(4). Available at: https://aisel.aisnet.org/misq/vol37/iss4/7.

Aggarwal VA, Hsu DH. 2014. Entrepreneurial Exits and Innovation. Management Science. INFORMS 60(4): 867-887. Available at: http://pubsonline.informs.org/doi/abs/10.1287/mnsc.2013.1801.

Alvarez-Garrido E, Dushnitsky G. 2016. Are entrepreneurial venture's innovation rates sensitive to investor complementary assets? Comparing biotech ventures backed by corporate and independent VCs. Strategic Management Journal. Wiley-Blackwell 37(5): 819-834. Available at: http://doi.wiley.com/10.1002/smj.2359.

Amara N, Landry R, Traoré N. 2008. Managing the protection of innovations in knowledge-intensive business services. Research Policy 37(9): 1530-1547. Available at: http://linkinghub.elsevier.com/retrieve/pii/S0048733308001509.

Ambos TC, Birkinshaw J. 2010. How Do New Ventures Evolve? An Inductive Study of Archetype Changes in Science-Based Ventures. Organization Science 21(6): 1125-1140. Available at: http://orgsci.journal.informs.org/content/21/6/1125.abstract.

Andrews DWK, Buchinsky M. 2000. A Three-step Method for Choosing the Number of Bootstrap Repetitions. Econometrica. Wiley Online Library 68(1): 23-51.

Andries P, Debackere K, van Looy B. 2013. Simultaneous experimentation as a learning strategy: Business model development under uncertainty. Strategic Entrepreneurship Journal 7(4): 288-310. Available at: http://doi.wiley.com/10.1002/sej.1170.

Arora A, Fosfuri A, Gambardella A. 2001. Markets for Technology and their Implications for Corporate Strategy. Industrial and Corporate Change. Oxford University Press 10(2): 419-451. Available at: https://academic.oup.com/icc/article-lookup/doi/10.1093/icc/10.2.419.

Arqué-Castells P. 2012. How venture capitalists spur invention in Spain: Evidence from patent trajectories. Research Policy 41(5): 897-912. Available at: http://linkinghub.elsevier.com/retrieve/pii/S0048733312000224.

Bajo E, Raimondo C. 2017. Media sentiment and IPO underpricing. Journal of Corporate Finance. North-Holland 46: 139-153. Available at: https://www.sciencedirect.com/science/article/pii/S092911991730370X.

Bantel KA, Jackson SE. 1989. Top management and innovations in banking: Does the composition of the top team make a difference? Strategic Management Journal. Wiley-Blackwell 10(S1): 107-124. Available at: http://doi.wiley.com/10.1002/smj.4250100709.

Barney JB, Ketchen DJ, Wright M. 2011. The Future of Resource-Based Theory. Journal of Management, Barney JB, Ketchen DJ, Wright M (eds). SAGE PublicationsSage CA: Los Angeles, CA 37(5): 1299-1315. Available at: http://journals.sagepub.com/doi/10.1177/0149206310391805. 
Bawa R, Bawa SR, Maebius SB, Flynn T, Wei C. 2005. Protecting new ideas and inventions in nanomedicine with patents. Nanomedicine: Nanotechnology, Biology and Medicine. Elsevier 1(2): 150-158. Available at: https://www.sciencedirect.com/science/article/pii/S1549963405000675.

Beckman CM, Burton MD, O'Reilly C. 2007. Early teams: The impact of team demography on VC financing and going public. Journal of Business Venturing 22(2): 147-173. Available at: http://linkinghub.elsevier.com/retrieve/pii/S0883902606000280.

Bertoni F, Colombo MG, Grilli L. 2011. Venture capital financing and the growth of high-tech start-ups: Disentangling treatment from selection effects. Research Policy 40(7): 10281043. Available at: http://www.sciencedirect.com/science/article/pii/S0048733311000515.

Bertoni F, D'Adda D, Grilli L. 2018. Self-selection of entrepreneurial firms in thin venture capital markets: Theory and empirical evidence. Strategic Entrepreneurship Journal. John Wiley \& Sons, Ltd. Available at: http://doi.wiley.com/10.1002/sej.1280.

Bertoni F, Tykvová T. 2015. Does governmental venture capital spur invention and innovation? Evidence from young European biotech companies. Research Policy 44(4): 925-935. Available at: http://linkinghub.elsevier.com/retrieve/pii/S004873331500030X.

Blackwell M, Iacus S, King G, Porro G. 2009. cem: Coarsened exact matching in Stata. Stata Journal. StataCorp LP 9(4): 524-546. Available at: https://ideas.repec.org/a/tsj/stataj/v9y2009i4p524-546.html.

Block JH, Fisch C, Sandner PG. 2014a. Trademark families: Characteristics and market values. Journal of Brand Management. Palgrave Macmillan UK 21(2): 150-170. Available at: http://link.springer.com/10.1057/bm.2013.27.

Block JH, De Vries G, Schumann JH, Sandner P. 2014b. Trademarks and venture capital valuation. Journal of Business Venturing 29(4): 525-542. Available at: http://linkinghub.elsevier.com/retrieve/pii/S0883902613000724.

Boeker W, Wiltbank R. 2005. New Venture Evolution and Managerial Capabilities. Organization Science 16(2): 123-133. Available at: http://orgsci.journal.informs.org/cgi/doi/10.1287/orsc.1050.0115.

Bresciani S, Eppler MJ. 2010. Brand new ventures? Insights on start-ups' branding practices. Journal of Product \& Brand Management. Emerald Group Publishing Limited 19(5): 356-366. Available at: http://www.emeraldinsight.com/doi/10.1108/10610421011068595.

Brush CG, Greene PG, Hart MM. 2001. From initial idea to unique advantage: The entrepreneurial challenge of constructing a resource base. Academy of Management Perspectives. Academy of Management 15(1): 64-78. Available at: http://amp.aom.org/cgi/doi/10.5465/AME.2001.4251394.

Burgelman RA, Grove AS. 2007. Cross-boundary disruptors: powerful interindustry entrepreneurial change agents. Strategic Entrepreneurship Journal 1(3-4): 315-327. Available at: http://doi.wiley.com/10.1002/sej.27.

Chandy RK, Hopstaken B, Narasimhan O, Prabhu J. 2006. From Invention to Innovation: Conversion Ability in Product Development. Journal of Marketing Research 43(3): 494508. Available at: http://www.atypon-link.com/AMA/doi/abs/10.1509/jmkr.43.3.494.

Ching K, Gans JS, Stern S. 2017. Control Versus Execution: Endogenous Appropriability and 
Entrepreneurial Strategy. SSRN Electronic Journal. Available at: http://www.ssrn.com/abstract=2946078.

Choi YR, Lévesque M, Shepherd D a. 2008. When should entrepreneurs expedite or delay opportunity exploitation? Journal of Business Venturing 23(3): 333-355. Available at: http://linkinghub.elsevier.com/retrieve/pii/S0883902606001030.

Clarysse B, Bruneel J, Wright M. 2011. Explaining growth paths of young technology-based firms: structuring resource portfolios in different competitive environments. Strategic Entrepreneurship Journal 5(2): 137-157. Available at: http://doi.wiley.com/10.1002/sej.111.

Croce A, Martí J, Murtinu S. 2013. The impact of venture capital on the productivity growth of European entrepreneurial firms: 'Screening' or 'value added' effect? Journal of Business Venturing 28(4): 489-510. Available at: http://www.sciencedirect.com/science/article/pii/S0883902612000705.

Davila A, Foster G, Gupta M. 2003. Venture capital financing and the growth of startup firms. Journal of Business Venturing 18(6): 689-708. Available at: http://www.sciencedirect.com/science/article/pii/S0883902602001271.

Deephouse DL. 2000. Media Reputation as a Strategic Resource: An Integration of Mass Communication and Resource-Based Theories. Journal of Management. Sage PublicationsSage CA: Thousand Oaks, CA 26(6): 1091-1112. Available at: http://journals.sagepub.com/doi/10.1177/014920630002600602.

Dushnitsky G, Lenox MJ. 2005. When do incumbents learn from entrepreneurial ventures? Research Policy 34(5): 615-639. Available at: http://linkinghub.elsevier.com/retrieve/pii/S0048733305000442.

Engel D, Keilbach M. 2007. Firm-level implications of early stage venture capital investment - An empirical investigation. Journal of Empirical Finance 14(2): 150-167. Available at: http://www.sciencedirect.com/science/article/pii/S0927539806000442.

EUIPO. 2017. Trade mark definition - EUTM. Available at: https://euipo.europa.eu/ohimportal/en/trade-mark-definition [26 June 2017].

Fernhaber SA, Patel PC. 2012. How do young firms manage product portfolio complexity? the role of absorptive capacity and ambidexterity. Strategic Management Journal (July 2010): n/a-n/a. Available at: http://doi.wiley.com/10.1002/smj.1994.

De Figueiredo RJP, Meyer-Doyle P, Rawley E. 2013. Inherited agglomeration effects in hedge fund spawns. Strategic Management Journal. John Wiley \& Sons, Ltd 34(7): 843-862. Available at: http://doi.wiley.com/10.1002/smj.2048.

Fitza M, Matusik SF, Mosakowski E. 2009. Do VCs matter? the importance of owners on performance variance in start-up firms. Strategic Management Journal 30(4): 387-404. Available at: http://doi.wiley.com/10.1002/smj.748.

Flikkema M, De Man A-P, Castaldi C. 2014. Are Trademark Counts a Valid Indicator of Innovation? Results of an In-Depth Study of New Benelux Trademarks Filed by SMEs. Industry and Innovation. Routledge 21(4): 310-331. Available at: http://www.tandfonline.com/doi/abs/10.1080/13662716.2014.934547.

Gallié E-P, Legros D. 2012. French firms' strategies for protecting their intellectual property. Research Policy 41(4): 780-794. Available at: http://linkinghub.elsevier.com/retrieve/pii/S0048733311002307. 
Germann F, Ebbes P, Grewal R. 2015. The Chief Marketing Officer Matters! Journal of Marketing. American Marketing Association 79(3): 1-22. Available at: http://journals.ama.org/doi/10.1509/jm.14.0244.

Giarratana MS, Torrisi S. 2010. Foreign entry and survival in a knowledge-intensive market: emerging economy countries' international linkages, technology competences, and firm experience. Strategic Entrepreneurship Journal. Wiley-Blackwell 4(1): 85-104. Available at: http://doi.wiley.com/10.1002/sej.84.

Gompers P, Lerner J. 2001. The Venture Capital Revolution. Journal of Economic Perspectives 15(2): 145-168. Available at: http://pubs.aeaweb.org/doi/10.1257/jep.15.2.145.

Granqvist N, Grodal S, Woolley JL. 2013. Hedging Your Bets: Explaining Executives' Market Labeling Strategies in Nanotechnology. Organization Science 24(2): 395-413. Available at: http://pubsonline.informs.org/doi/10.1287/orsc.1120.0748.

Greenhalgh C, Rogers M. 2012. Trade Marks and Performance in Services and Manufacturing Firms: Evidence of Schumpeterian Competition through Innovation. Australian Economic Review 45(1): 50-76. Available at: http://doi.wiley.com/10.1111/j.1467-8462.2011.00665.x.

Grodal S. 2018. Field Expansion and Contraction: How Communities Shape Social and Symbolic Boundaries. Administrative Science Quarterly. SAGE PublicationsSage CA: Los Angeles, CA 63(4): 783-818. Available at: http://journals.sagepub.com/doi/10.1177/0001839217744555.

Guzman J, Stern S. 2015. Where is Silicon Valley? Science 347(6222): 606-609. Available at: http://www.sciencemag.org/content/347/6222/606.full.

Hannan MT, Pólos L, Carroll GR. 2003. Cascading Organizational Change. Organization Science. INFORMS 14(5): 463-482. Available at: http://pubsonline.informs.org/doi/abs/10.1287/orsc.14.5.463.16763.

Hellmann T, Puri M. 2000. The Interaction between Product Market and Financing Strategy: The Role of Venture Capital. Review of Financial Studies 13(4): 959-984. Available at: http://rfs.oxfordjournals.org/content/13/4/959.short.

Hellmann T, Puri M. 2002. Venture Capital and the Professionalization of Start-Up Firms: Empirical Evidence. The Journal of Finance 57(1): 169-197. Available at: http://www.blackwell-synergy.com/doi/abs/10.1111/1540-6261.00419.

Hitt M a., Ireland RD, Camp SM, Sexton DL. 2001. Strategic entrepreneurship: entrepreneurial strategies for wealth creation. Strategic Management Journal 22(6-7): 479-491. Available at: http://doi.wiley.com/10.1002/smj.196.

Hsu DH. 2006. Venture Capitalists and Cooperative Start-up Commercialization Strategy. Management Science. INFORMS 52(2): 204-219. Available at: http://pubsonline.informs.org/doi/abs/10.1287/mnsc.1050.0480.

Huckman RS, Zinner DE. 2008. Does focus improve operational performance? Lessons from the management of clinical trials. Strategic Management Journal. Wiley Online Library 29(2): 173-193. Available at: http://onlinelibrary.wiley.com/doi/10.1002/smj.650/abstract.

Iacus SM, King G, Porro G. 2011. Multivariate Matching Methods That Are Monotonic Imbalance Bounding. Journal of the American Statistical Association. Taylor \& Francis 
106(493): 345-361. Available at:

http://www.tandfonline.com/doi/abs/10.1198/jasa.2011.tm09599.

Iacus SM, King G, Porro G. 2012. Causal Inference without Balance Checking: Coarsened Exact Matching. Political Analysis. Cambridge University Press 20(01): 1-24. Available at:

https://www.cambridge.org/core/product/identifier/S1047198700012985/type/journal_ar ticle.

Johnson RA, Hoskisson RE, Hitt MA. 1993. Board of director involvement in restructuring: The effects of board versus managerial controls and characteristics. Strategic Management Journal 14(S1): 33-50. Available at: http://doi.wiley.com/10.1002/smj.4250140905.

Katila R, Chen EL, Piezunka H. 2012. All the right moves: How entrepreneurial firms compete effectively. Strategic Entrepreneurship Journal 6(2): 116-132. Available at: http://doi.wiley.com/10.1002/sej.1130.

Ketchen DJ, Ireland RD, Snow CC. 2007. Strategic entrepreneurship, collaborative innovation, and wealth creation. Strategic Entrepreneurship Journal 1(3-4): 371-385. Available at: http://doi.wiley.com/10.1002/sej.20.

Klingebiel R. 2012. Options in the Implementation Plan of Entrepreneurial Initiatives: Examining Firms' Attainment of Flexibility Benefit. Strategic Entrepreneurship Journal 6(4): 307-334. Available at: http://doi.wiley.com/10.1002/sej.1142.

Kotha R, Zheng Y, George G. 2011. Entry into new niches: the effects of firm age and the expansion of technological capabilities on innovative output and impact. Strategic Management Journal 32(9): 1011-1024. Available at: http://doi.wiley.com/10.1002/smj.915.

Krasnikov A, Mishra S, Orozco D. 2009. Evaluating the Financial Impact of Branding Using Trademarks: A Framework and Empirical Evidence. Journal of Marketing. American Marketing Association 73(6): 154-166. Available at: http://journals.ama.org/doi/abs/10.1509/jmkg.73.6.154.

Krishnan V, Ulrich KT. 2001. Product development decisions: A review of the literature. Management Science. JSTOR 47(1): 1-21. Available at: http://www.jstor.org/stable/2661556.

Lahr H, Mina A. 2016. Venture capital investments and the technological performance of portfolio firms. Research Policy 45(1): 303-318. Available at: http://linkinghub.elsevier.com/retrieve/pii/S0048733315001481.

Lambert-Pandraud R, Laurent G. 2010. Why Do Older Consumers Buy Older Brands? The Role of Attachment and Declining Innovativeness. Journal of Marketing 74(5): 104-121. Available at: http://www.atypon-link.com/AMA/doi/abs/10.1509/jmkg.74.5.104.

Lee BH, Struben J, Bingham CB. 2018. Collective action and market formation: An integrative framework. Strategic Management Journal. Wiley-Blackwell 39(1): 242-266. Available at: http://doi.wiley.com/10.1002/smj.2694.

Leiponen A, Helfat CE. 2009. Innovation objectives, knowledge sources, and the benefits of breadth. Strategic Management Journal. Wiley Online Library 31(2): n/a-n/a. Available at: http://doi.wiley.com/10.1002/smj.807.

Levinthal DA, Wu B. 2010. Opportunity costs and non-scale free capabilities: profit 
maximization, corporate scope, and profit margins. Strategic Management Journal. John Wiley \& Sons, Ltd. 31(7): n/a-n/a. Available at: http://doi.wiley.com/10.1002/smj.845.

Lockett A, Murray G, Wright M. 2002. Do UK venture capitalists still have a bias against investment in new technology firms. Research Policy. North-Holland 31(6): 1009-1030. Available at: https://www.sciencedirect.com/science/article/abs/pii/S0048733301001743.

Madden TJ, Fehle F, Fournier S. 2006. Brands Matter: An Empirical Demonstration of the Creation of Shareholder Value Through Branding. Journal of the Academy of Marketing Science. Sage PublicationsSage CA: Thousand Oaks, CA 34(2): 224-235. Available at: http://link.springer.com/10.1177/0092070305283356.

Marx M, Gans JS, Hsu DH. 2014. Dynamic Commercialization Strategies for Disruptive Technologies: Evidence from the Speech Recognition Industry. Management Science. INFORMS 60(12): 3103-3123. Available at: http://pubsonline.informs.org/doi/abs/10.1287/mnsc.2014.2035.

Mendonça S et al. 2004. Trademarks as an indicator of innovation and industrial change. Research Policy 33(9): 1385-1404. Available at: http://linkinghub.elsevier.com/retrieve/pii/S0048733304001222.

Morgan NA, Vorhies DW, Mason CH. 2009. Market orientation, marketing capabilities, and firm performance. Strategic Management Journal 30(8): 909-920. Available at: http://doi.wiley.com/10.1002/smj.764.

Munari F, Toschi L. 2014. Running ahead in the nanotechnology gold rush. Strategic patenting in emerging technologies. Technological Forecasting and Social Change. North-Holland 83: 194-207. Available at: https://www.sciencedirect.com/science/article/pii/S0040162513001546.

Munari F, Toschi L. 2015. Assessing the impact of public venture capital programmes in the United Kingdom: Do regional characteristics matter? Journal of Business Venturing. Elsevier 30(2): 205-226. Available at: https://www.sciencedirect.com/science/article/abs/pii/S0883902614000706.

Ott TE, Eisenhardt KM, Bingham CB. 2017. Strategy Formation in Entrepreneurial Settings: Past Insights and Future Directions. Strategic Entrepreneurship Journal. John Wiley \& Sons, Ltd 11(3): 306-325. Available at: http://doi.wiley.com/10.1002/sej.1257.

Pahnke EC, Katila R, Eisenhardt KM. 2015. Who Takes You to the Dance? How Partners' Institutional Logics Influence Innovation in Young Firms. Administrative Science Quarterly 60(4): 596-633. Available at: http://asq.sagepub.com/content/60/4/596.

Posen HE, Levinthal DA. 2012. Chasing a Moving Target: Exploitation and Exploration in Dynamic Environments. Management Science 58(3): 587-601. Available at: http://mansci.journal.informs.org/content/58/3/587.abstract.

Ramello GB, Silva F. 2006. Appropriating signs and meaning: the elusive economics of trademark. Industrial and Corporate Change 15(6): 937-963. Available at: http://icc.oxfordjournals.org/content/15/6/937.full.

Ref O, Shapira Z. 2017. Entering new markets: The effect of performance feedback near aspiration and well below and above it. Strategic Management Journal. John Wiley \& Sons, Ltd 38(7): 1416-1434. Available at: http://doi.wiley.com/10.1002/smj.2561.

Rindova VP, Yeow A, Martins LL, Faraj S. 2012. Partnering portfolios, value-creation logics, 
and growth trajectories: A comparison of Yahoo and Google (1995 to 2007). Strategic Entrepreneurship Journal 6(2): 133-151. Available at:

http://doi.wiley.com/10.1002/sej.1131.

Rode V, Vallaster C. 2005. Corporate Branding for Start-ups: The Crucial Role of

Entrepreneurs. Corporate Reputation Review 8(2): 121-135. Available at:

http://link.springer.com/10.1057/palgrave.crr.1540244.

Rujas J. 1999. Trade marks: complementary to patents. World Patent Information 21(1): 3539. Available at: http://linkinghub.elsevier.com/retrieve/pii/S017221909900023X.

Sakhartov A V., Folta TB. 2014. Resource relatedness, redeployability, and firm value. Strategic Management Journal. John Wiley \& Sons, Ltd 35(12): 1781-1797. Available at: http://doi.wiley.com/10.1002/smj.2182.

Samila S, Sorenson O. 2010. Venture capital as a catalyst to commercialization. Research Policy 39(10): 1348-1360. Available at: http://linkinghub.elsevier.com/retrieve/pii/S0048733310001782.

Sarangee KR, Echambadi R. 2014. Firm-Specific Determinants of Product Line Technology Strategies in High Technology Markets. Strategic Entrepreneurship Journal 8(2): 149166. Available at: http://doi.wiley.com/10.1002/sej.1164.

Sine WD, Mitsuhashi H, Kirsch D a. 2006. REVISITING BURNS AND STALKER: FORMAL STRUCTURE AND NEW VENTURE PERFORMANCE IN EMERGING ECONOMIC SECTORS. Academy of Management Journal 49(1): 121-132. Available at: http://connection.ebscohost.com/an/20785590.

Singh J, Agrawal A. 2011. Recruiting for Ideas: How Firms Exploit the Prior Inventions of New Hires. Management Science 57(1): 129-150. Available at: http://pubsonline.informs.org/doi/abs/10.1287/mnsc.1100.1253.

Slotegraaf RJ, Atuahene-Gima K. 2011. Product Development Team Stability and New Product Advantage: The Role of Decision-Making Processes. Journal of Marketing 75(1): 96-108. Available at: http://journals.ama.org/doi/abs/10.1509/jmkg.75.1.96.

SØRENSEN M. 2007. How Smart Is Smart Money? A Two-Sided Matching Model of Venture Capital. The Journal of Finance 62(6): 2725-2762. Available at: http://doi.wiley.com/10.1111/j.1540-6261.2007.01291.x.

Stock JJ, Yogo M. 2002. Testing for weak instruments in linear IV regression. NBER Working Paper. Cambridge, MA. Available at: http://www.nber.org/papers/t0284.pdf.

TechCrunch. 2012. Why The Source Of Venture Capital Is As Important As The Money Itself | TechCrunch. Available at:

http://techcrunch.com/2012/09/04/why-the-source-of-venture-capital-is-as-important-asthe-money-itself/ [30 November 2014].

Tortoriello M, McEvily B, Krackhardt D. 2015. Being a Catalyst of Innovation: The Role of Knowledge Diversity and Network Closure. Organization Science 26(2): 423-438. Available at: http://pubsonline.informs.org/doi/10.1287/orsc.2014.0942.

USPTO. 2018. Trademark Manual of Examining Procedure. Available at: https://mep.uspto.gov/RDMS/TMEP/current\#/current/TMEP-1200d1e2882.html [2 November 2018].

Vomberg A, Homburg C, Bornemann T. 2014. Talented people and strong brands: The contribution of human capital and brand equity to firm value. Strategic Management 
Journal : n/a-n/a. Available at: http://doi.wiley.com/10.1002/smj.2328.

Wernerfelt B. 1984. A resource-based view of the firm. Strategic Management Journal. John Wiley \& Sons, Ltd. 5(2): 171-180. Available at: http://doi.wiley.com/10.1002/smj.4250050207.

Wooldridge J. 2002. Introductory Econometrics: A Modern Approach, 2nd ed. Economic Analysis. South-Western College Pub.

Wry T, Lounsbury M, Jennings PD. 2014. Hybrid Vigor: Securing Venture Capital by Spanning Categories in Nanotechnology. Academy of Management Journal. Academy of Management 57(5): 1309-1333. Available at: http://amj.aom.org/content/57/5/1309.full.

Wu B. 2013. Opportunity costs, industry dynamics, and corporate diversification: Evidence from the cardiovascular medical device industry, 1976-2004. Strategic Management Journal. John Wiley \& Sons, Ltd 34(11): 1265-1287. Available at: http://doi.wiley.com/10.1002/smj.2069. 
TABLES \& FIGURES

Table 1 - Summary of Variables and Data Sources

\section{Variable}

\section{Dependent Variables}

Number of Brand Assets

Brand Asset Scope

\section{Explanatory Variables}

VC Backing

\section{Control Variables}

TMT Experience

TMT PhD

TMT Marketing or Legal

TMT Age Disparity

Firm Age

Firm Innovative Productivity

Year Dummies

Region Dummies
Measure Description

Data Sources

Total number of filed trademarks OHIM and UK IPO by the focal firm at year $t$

Average number of different

OHIM and UK IPO goods and services classes reported in the trademarks filed by the focal firm at year $t$

Dummy with value 1 for VC-backed firms from the first year of VC funding onwards

Thomson One

Dummy with value 1 if any

FAME; Company company director has previous Director Check directorship experience in other firms

Dummy equal to 1 if any director received a $\mathrm{PhD}$

FAME; Company

Director Check

Dummy with value 1 if any

FAME; Company company director in the firm at year $t$ has previous experience in the marketing and/or legal function.

Heterogeneity in the age of the

FAME top management team members of the of the focal firm at year $t$ Firm age at year $t$

Director Check

Citation-weighted patent stock at year $\mathrm{t}$

A set of 16-year dummies

A set of 12 dummies indicating in which among the 12 first level regions within the UK the firm is located.

\section{MNT Network}

Orbit

MNT Network

MNT Network 
Instrumental Variable

Firm Media Sentiment

Coefficient of Media

Lexis Nexis

Favourableness (Aggarwal and

Singh, 2013; Deephouse, 2000)

This article is protected by copyright. All rights reserved. 
Table 2 - Descriptive Statistics and Correlations

\begin{tabular}{|c|c|c|c|c|c|c|c|c|c|c|c|c|c|c|c|c|}
\hline & Variable & Obs. & Mean & Std. & Min & Max & 1 & 2 & 3 & 4 & 5 & 6 & 7 & 8 & 9 & 10 \\
\hline 1 & Number of Brand Assets & 2,074 & 0.14 & 0.65 & 0 & 15 & 1 & & & & & & & & & \\
\hline 2 & Brand Asset Scope & 2,074 & 0.20 & 1.02 & 0 & 19 & $0.64 *$ & 1 & & & & & & & & \\
\hline 3 & VC Backing & 2,074 & 0.27 & 0.45 & 0 & 1 & $0.08^{*}$ & $0.05^{*}$ & 1 & & & & & & & \\
\hline 4 & TMT Experience & 1,868 & 0.87 & 0.34 & 0 & 1 & $0.07 *$ & $0.06^{*}$ & $0.15^{*}$ & 1 & & & & & & \\
\hline 5 & TMT PhD & 1,963 & 0.68 & 0.47 & 0 & 1 & 0.04 & 0.03 & $0.10 *$ & 0.03 & 1 & & & & & \\
\hline 6 & TMT Age Disparity & 1,895 & 0.42 & 0.25 & 0 & 0.78 & $0.05^{*}$ & 0.02 & $0.21 *$ & $0.39 *$ & $0.28 *$ & 1 & & & & \\
\hline 7 & Firm Age & 2,074 & 5.26 & 3.63 & 0 & 15 & -0.01 & -0.01 & $0.17 *$ & $0.05 *$ & 0.01 & $0.09 *$ & 1 & & & \\
\hline 8 & Firm Innovative Productivity & 1,934 & 0.11 & 0.49 & 0 & 8 & 0 & 0 & $0.12 *$ & $-0.06^{*}$ & $-0.09 *$ & 0.01 & $0.09 *$ & 1 & & \\
\hline 9 & TMT Marketing or Legal & 2,074 & 0.09 & 0.29 & 0 & 1 & 0.01 & 0.01 & $-0.07 *$ & $0.11^{*}$ & -0.03 & $0.11 *$ & $-0.11^{*}$ & $0.12 *$ & 1 & \\
\hline 10 & Firm Media Sentiment & 1,934 & 0.25 & 0.37 & -1 & 1 & 0.04 & 0.03 & $0.16^{*}$ & 0.04 & $0.05^{*}$ & $0.09 *$ & $0.14 *$ & -0.02 & $-0.07 *$ & 1 \\
\hline
\end{tabular}

$$
* p<0.05
$$


Table 3 - VC Backing and Brand Strategy

\begin{tabular}{|c|c|c|c|c|c|c|c|}
\hline & (1) & (2) & (3) & (4) & (5) & (6) & (7) \\
\hline & Negativ & nomial & CEM Nega & Binomial & 2SRI Nega & Binomial $^{\mathrm{a}}$ & 2SRI First Stage ${ }^{b}$ \\
\hline & $\begin{array}{c}\text { Number of } \\
\text { Brand Assets }\end{array}$ & $\begin{array}{c}\text { Brand Asset } \\
\text { Scope }\end{array}$ & $\begin{array}{c}\text { Number of } \\
\text { Brand Assets }\end{array}$ & $\begin{array}{c}\text { Brand Asset } \\
\text { Scope }\end{array}$ & $\begin{array}{c}\text { Number of } \\
\text { Brand Assets }\end{array}$ & $\begin{array}{c}\text { Brand Asset } \\
\text { Scope }\end{array}$ & VC Backing \\
\hline VC Backing & $0.56^{*}$ & $0.61^{*}$ & $0.79^{*}$ & $0.79^{*}$ & $0.65^{+}$ & $0.69^{+}$ & \\
\hline & $(0.25)$ & $(0.26)$ & $(0.34)$ & $(0.34)$ & $(0.35)$ & $(0.37)$ & \\
\hline TMT Experience & $0.89^{+}$ & 0.81 & 0.05 & 0.04 & 0.85 & 0.80 & 1.69 \\
\hline & $(0.54)$ & $(0.55)$ & $(0.08)$ & $(0.08)$ & $(1.07)$ & $(1.07)$ & (1.09) \\
\hline TMT PhD & 0.07 & 0.04 & $1.43^{+}$ & $1.44^{+}$ & -0.27 & -0.32 & 0.52 \\
\hline & $(0.26)$ & $(0.26)$ & $(0.83)$ & $(0.85)$ & $(0.31)$ & $(0.33)$ & $(0.72)$ \\
\hline TMT Age Disparity & 0.55 & 0.55 & 0.07 & 0.01 & -1.65 & -1.63 & $4.83^{*}$ \\
\hline & $(0.49)$ & $(0.50)$ & $(0.32)$ & $(0.32)$ & $(1.04)$ & $(1.09)$ & $(2.21)$ \\
\hline TMT Marketing Legal & 0.11 & 0.14 & $0.75^{+}$ & $1.00^{*}$ & 0.04 & 0.03 & 0.04 \\
\hline & $(0.32)$ & $(0.32)$ & $(0.41)$ & $(0.40)$ & $(0.32)$ & $(0.40)$ & $(0.52)$ \\
\hline Firm Age & 0.02 & 0.05 & $-1.26^{*}$ & $-1.25^{+}$ & -0.07 & -0.05 & 0.28 \\
\hline & $(0.06)$ & $(0.06)$ & $(0.63)$ & $(0.66)$ & $(0.09)$ & $(0.10)$ & $(0.26)$ \\
\hline Firm Innovative Productivity & -0.09 & -0.24 & $0.78^{+}$ & $0.87^{+}$ & 0.18 & 0.02 & 0.45 \\
\hline & $(0.28)$ & $(0.29)$ & $(0.47)$ & $(0.48)$ & $(0.36)$ & $(0.37)$ & $(1.00)$ \\
\hline Firm Media Sentiment & & & & & & & $2.43^{*}$ \\
\hline & & & & & & & $(1.01)$ \\
\hline First Stage Residual & & & & & $-1.89^{* * *}$ & $-1.90^{* * *}$ & \\
\hline & & & & & $(0.51)$ & $(0.54)$ & \\
\hline Year FE & YES & YES & YES & YES & YES & YES & YES \\
\hline
\end{tabular}




\begin{tabular}{|c|c|c|c|c|c|c|c|}
\hline Region FE & YES & YES & YES & YES & YES & YES & YES \\
\hline Observations & 1695 & 1695 & 846 & 846 & 1695 & 1695 & 1692 \\
\hline Firms & 178 & 178 & 153 & 153 & 178 & 178 & 178 \\
\hline$A I C$ & 1210.69 & 1362.22 & 716.87 & 805.49 & 1192.01 & 1344.59 & 508.28 \\
\hline$B I C$ & 1400.93 & 1552.46 & 873.30 & 961.93 & 1387.69 & 1540.27 & 687.59 \\
\hline
\end{tabular}

${ }^{+} p<0.10,{ }^{*} p<0.05,{ }^{* *} p<0.01,{ }^{* * *} p<0.001$ Standard errors in parentheses. ${ }^{\mathrm{a}}$ Bootstrap standard errors (based on 1000 replications). ${ }^{\mathrm{b}}$ Probit. 
Figure 1 - Number of Trademarks Filed and Timing of Trademarking Activity in VC-backed Companies

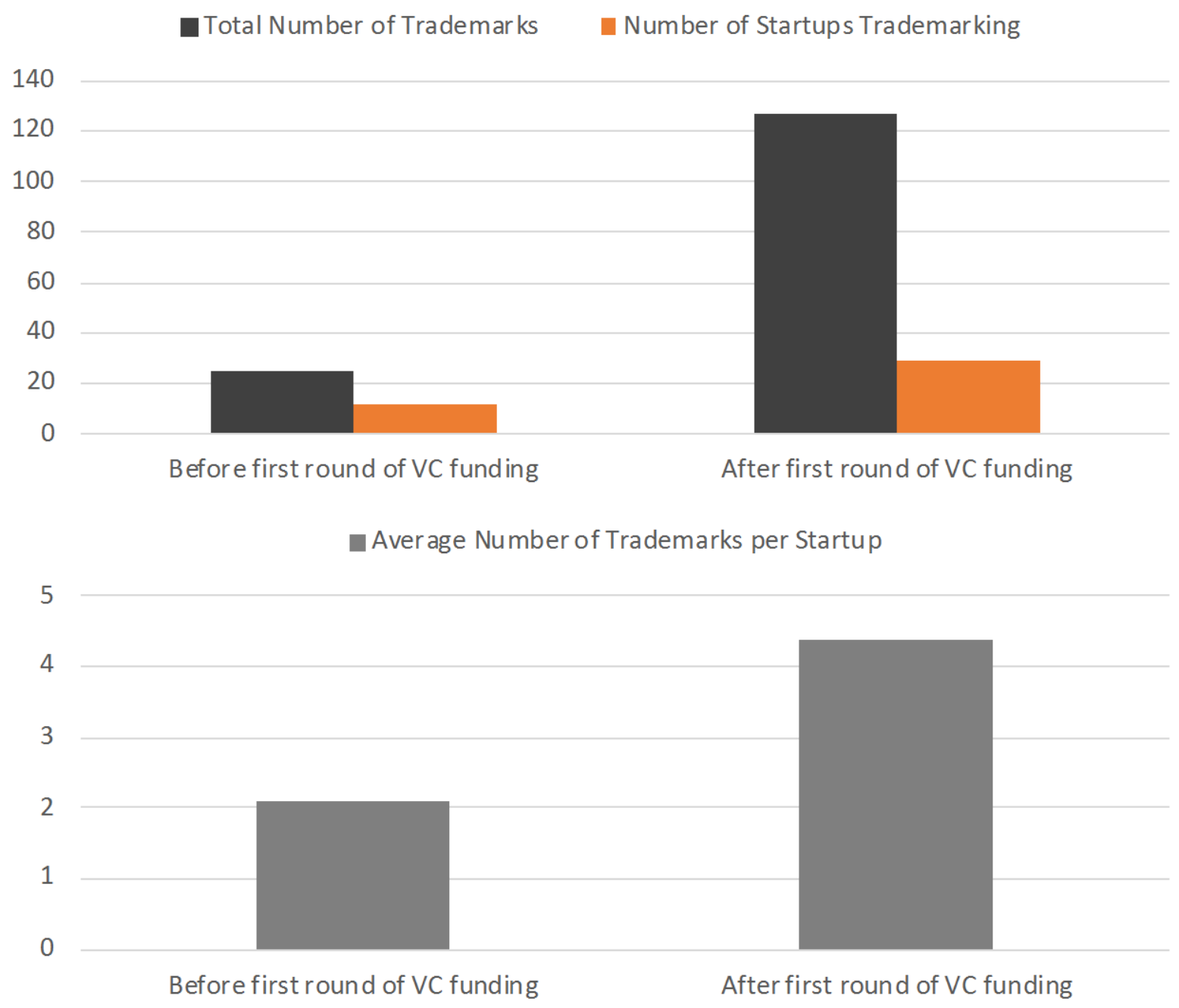

This article is protected by copyright. All rights reserved. 